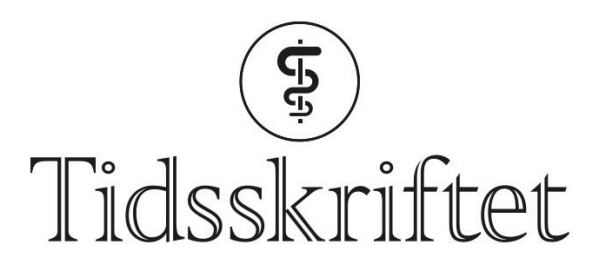

DEN NORSKE LEGEFORENING

\title{
Merete Akselsen
}

MINNEORD

HANS JOACHIM HAUSS

MARTE CAMERON

LINDA REME SAGEDAL

KRISTIN KJELLEVOLD

ANNE WAAGE

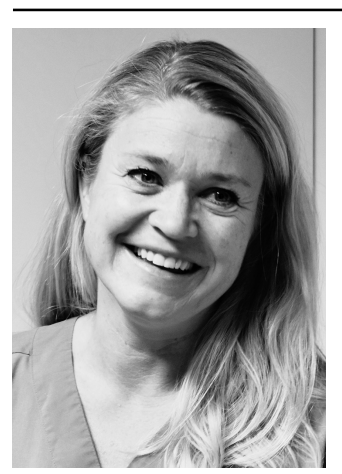

Merete Akselsen (født Andersen) døde 9. april 2021, bare 52 år gammel. Hun ble plutselig kreftsyk i april 2019, men kom seg tilbake til jobb og en aktiv hverdag før sykdommen dessverre tok overhånd senhøsten 2020.

Merete vokste opp i Kristiansand og studerte medisin ved Universitetet i Oslo. Hun giftet seg med Anders Akselsen i 1992. Mens hun fortsatt var medisinstudent, fikk de sønnen Anders Matias i 1994. Turnustjenesten hadde hun på Sykehuset i Moss og i Gildeskål kommune. Familien flyttet så tilbake til Moss og fikk døtrene Ingrid i 2000 og Amalie i 2004. Merete påbegynte utdannelsen i kirurgi ved sentralsykehuset i Østfold og fullførte gastrokirurgisk spesialitet ved Ullevål sykehus. Der gikk hun døgnvakter og var traumeteamleder mens hun dagpendlet mellom Oslo og Moss (buss, så T-bane og deretter $\emptyset$ stfoldbanen hjem til mann og tre barn). Hun dramatiserte det aldri, kommenterte bare på sin lakoniske måte at logistikken kunne være utfordrende.

I 2010 flyttet familien til Kristiansand for å være nærmere storfamilien. Merete fikk jobb som overlege ved Gastrokirurgisk seksjon ved Sørlandet sykehus, Kristiansand. Hun ble traumeansvarlig ved sykehuset og deltok i gjennomføring av avanserte traumekurs (ATLS). Hun engasjerte seg i utdanning av operasjonssykepleiere og avdelingens kvalitetsarbeid 
samt ble en ressurs for Kvinneklinikken i behandling av sfinkterskader etter fødsel.

Som kirurg var Merete nøyaktig og samvittighetsfull. Hun var dyktig og omsorgsfull i legegjerningen, behandlet sine pasienter med respekt og empati og hadde en imponerende arbeidskapasitet, stor integritet og yrkesstolthet. Merete var effektiv, fleksibel og et utpreget ja-menneske som var hundre prosent til å stole på. Egne meritter ble aldri fremhevet, men andre ble snakket opp. Hun var ivaretagende overfor yngre kolleger. Særlig ble hun en viktig rollemodell for kvinnelige leger, hvilket har hatt mye å si for rekruttering til kirurgiske fag ved Sørlandet sykehus.

Som venn var Merete raus og til stede, alltid omtenksom og ivaretagende. Vi beundret hennes styrke og hvordan hun grep inn der hun ante urett. Alltid stod hun opp for de svake og var aldri dømmende. Hun var intelligent, engasjert og humoristisk og en viktig del av det sosiale limet ved Kirurgisk avdeling.

Det er et stort tomrom og savn etter Merete, et flott menneske og kollega som vi var heldige å få kjenne. Vi kan bare begynne å ane hva dette tapet betyr for de som stod henne aller nærmest. Våre varmeste tanker går til Anders, barna og resten av familien.

På vegne av kollegaer og venner

Publisert: 7. juni 2021. Tidsskr Nor Legeforen. DOI: 10.4045/tidsskr.21.0363

(C) Tidsskrift for Den norske legeforening 2020. Lastet ned fra tidsskriftet.no 